\title{
Monoclonal Antibody Therapies for High Risk Neuroblastoma
}

\author{
Wayne L Furman (D) \\ Department of Oncology, St. Jude \\ Children's Research Hospital, Memphis, \\ TN, USA
}

\begin{abstract}
Monoclonal antibodies (mAbs) are part of the standard of care for the treatment of many adult solid tumors. Until recently none have been approved for use in children with solid tumors. Neuroblastoma (NB) is the most common extracranial solid tumor in children. Those with high-risk disease, despite treatment with very intensive multimodal therapy, still have poor overall survival. Results of treatment with an immunotherapy regimen using a chimeric (human/mouse) mAb against a cell surface disialoganglioside (GD2) have changed the standard of care for these children and resulted in the first approval of a mAb for use in children with solid tumors. This article will review the use of the various anti-GD2 mAbs in children with NB, methods that have been or are being evaluated for enhancing their efficacy, as well as review other promising antigenic targets for the therapeutic use of mAbs in children with NB.
\end{abstract}

Keywords: immunotherapy, neuroblastoma, anti-disialoganglioside, anti-GD2, chimeric, effector cells

\section{Introduction}

Monoclonal antibodies (mAbs) have developed into effective therapies for many adult malignancies. The global market for mAbs to treat cancer was estimated to be at more than 40 billion dollars in 2019 and likely to grow to more than 70 billion by 2024 (https://www.marketdataforecast.com/market-reports/global-cancer-

monoclonal-antibodies-market). Monoclonal antibodies kill cancer cells in several different ways: inhibiting cancer cell signaling, ${ }^{1-3}$ stimulating immune effector cells to destroy tumor cells (antibody-dependent cell-mediated cytotoxicity; ADCC), ${ }^{4}$ by fixing complement (complement-dependent cytotoxicity; CDC), resulting in assembly of a membrane attack complex and cell lysis (Figure 1$),{ }^{4}$ and by stimulating adaptive immunity. ${ }^{5}$ Other antibodies can cause changes in the tumor vasculature, resulting in improved treatment response. ${ }^{6}$ They have also been used as targeting agents by being coupled to toxic payloads such as drugs, ${ }^{7,8}$ toxins ${ }^{9}$ or radioisotopes (Figure 1). ${ }^{10,11}$ More recently mAbs have also been used to target cells in the tumor microenvironment resulting in enhanced anti-tumor immune responses., ${ }^{4,12}$

Neuroblastoma (NB) is the most common extracranial solid tumor in children and is thought to be derived from primitive neural crest cells. ${ }^{13}$ It can manifest anywhere along the sympathetic nervous system, with an adrenal mass being the most common primary site. ${ }^{14,15}$ "High-risk" NB is largely defined by patients older than 18 months of age at presentation with widely metastatic disease. ${ }^{16}$ Despite intensive multimodal treatment, more than half of these patients still die of their
Correspondence: Wayne L Furman Department of Oncology, St. Jude Children's Research Hospital, 262 Danny Thomas Place, Memphis, TN, 38105, USA Tel $+|-90|-595-2403$

Fax + I-90I-52I-9005

Email wayne.furman@stjude.org 


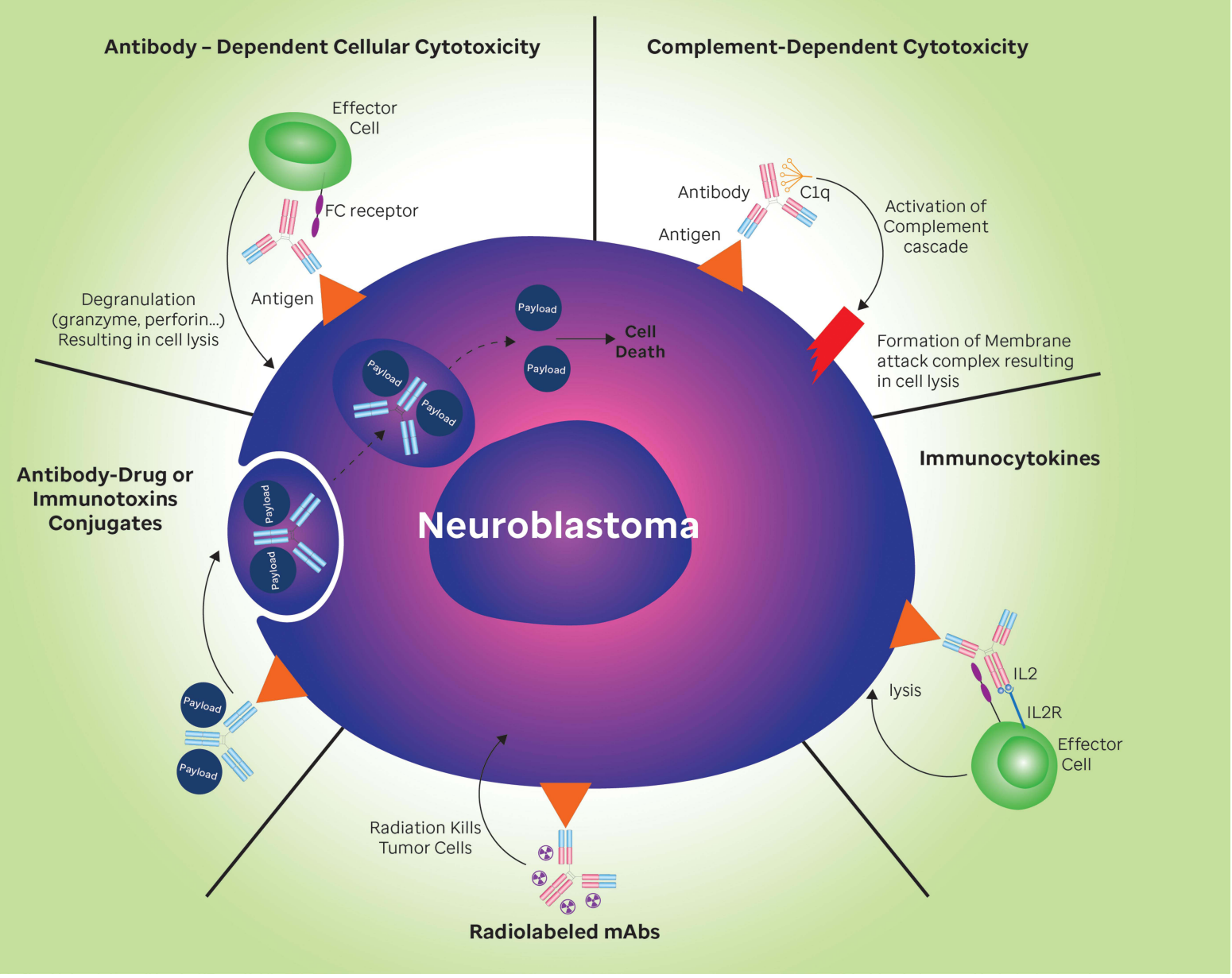

Figure I Antitumor mechanisms of GD2 antibodies and antibody conjugates. Solid triangle represents disialoganglioside (GD2) on cell surface.

disease. ${ }^{17}$ In the $1980 \mathrm{~s}$ it was discovered that neuroblasts almost uniformly express disialoganglioside (GD2) on their surfaces and this was used as a target to make several monoclonal antibodies, two of which have now been approved for use by the FDA ${ }^{18-25}$ (https://www.fda.gov/ drugs/drug-approvals-and-databases/fda-grants-accelerated -approval-naxitamab-high-risk-neuroblastoma-bone-orbone-marrow) and another approved by the European Medicines Agency (https://www.ema.europa.eu/en/medi cines/human/EPAR/qarziba\#: : text=The $\% 20$ European $\%$ 20Commission\%20granted $\% 20 \mathrm{a}$,Qarziba $\% 20$ on $\% 2027 \%$ 20November\%202017). The major anti-tumor mechanism of the anti-GD2 mAbs is likely ADCC mediated by NK cells $^{26}$ and to a lesser extent neutrophils and macrophages. ${ }^{27,28}$ This article will review the use of the anti-GD2 mAbs in children with $\mathrm{NB}$, methods that have been or are being evaluated for enhancing their efficacy, as well as review other promising antigenic targets for the therapeutic use of mAbs in children with NB.

\section{Immunotherapeutic Targets of Neuroblastoma \\ Disialoganglioside (GD2)}

Characteristics of antigens that make them attractive for $\mathrm{mAb}$ based therapy include consistent expression on the target cancer cells and limited expression on normal cells. One such antigen on neuroblasts is the disialoganglioside, GD2. ${ }^{19}$ While it is uniformly expressed on neuroblasts, ${ }^{19,20,29,30}$ in normal tissues it is expressed only on peripheral and central nerve fibers, ${ }^{31}$ mesenchymal stem cells, ${ }^{32,33}$ melanocytes ${ }^{34}$ and lymphocytes. ${ }^{31,35,36}$ It appears to have a role in attachment of tumor cells to the extracellular matrix, ${ }^{37}$ as well as effects on cell invasion and proliferation. ${ }^{29}$ Anti-GD2 mAbs that have been used 
clinically are summarized in Table 1 . The first to be evaluated in the clinic were the murine antibodies $3 \mathrm{~F} 8$ and 14G2a. Common acute toxicities to anti-GD2 mAbs include fever, hypotension, neuropathic pain and capillary leak syndrome (see Table 1). The fever and hypotension are likely related to allergic reactions to murine protein and pain due to $\mathrm{mAb}$ binding to GD2 positive peripheral nerves and subsequent complement activation. ${ }^{38,39}$ Capillary leak was more common during courses administered with interleukin-2 (IL-2) in the large randomized trial of dinutuximab ${ }^{25}$ and may be mostly related to systemically administered IL-2 or endogenous IL-2 produced in response to anti-GD2 mAb administration. $^{40,41}$

\section{Murine Anti-GD2 Antibodies}

\section{F8}

This murine IgG3 mAb specific for GD2, ${ }^{30}$ kills tumor cells by $\mathrm{ADCC}^{42}$ and by activating complement. ${ }^{30}$ It has been studied extensively in patients as a single agent ${ }^{21,43}$ and in combination with other agents used to enhance ADCC, such as GM-CSF ${ }^{42,44,45}$ and $\beta$-glucan (NCT00492167). ${ }^{46}$ There were some responses in patients with small amounts of bone and/or marrow disease but no responses in those with bulky disease. ${ }^{44,47-49}$ Human antimouse antibodies (HAMA) developed in a majority of patients treated with $3 \mathrm{~F} 8$. $^{49-52}$

\section{I4G2a}

This murine antibody is an isotype switch variant of the murine IgG3 14.18 anti-GD2 mAb. Because it had improved ADCC compared to 14.18, 14G2a was chosen for clinical evaluation. ${ }^{22}$ Two trials treated 27 patients at dosages from 50 to $400 \mathrm{mg} / \mathrm{m}^{2}{ }^{23,53}$ It was tolerated but with significant side effects (summarized in Table 1) and some modest anti-tumor activity. Human anti-mouse antibodies (HAMA) developed in 25/27 patients. $^{23,53}$ In an attempt to enhance ADCC it was combined with interleukin-2 in another Phase I study. Thirty-three patients were enrolled, 31 with NB. Pain and allergic reactions were common. Nine of 21 evaluable children developed HAMA. $^{54}$

Because murine antibodies result in allergic reactions and the development of HAMA, accelerating the clearance of the antibodies and reducing their antitumor effects, ${ }^{55}$ techniques to make antibodies "more human" have been developed. $^{56}$ Figure 2 depicts the general structure of antibodies and their engineering modifications which have been utilized to make them more tolerable.

\section{Chimeric Anti-GD2 Antibodies}

\section{Dinutuximab (Ch I4.18)}

To begin to address the immunogenic properties of murine anti-GD2 antibodies, the human Fc constant regions of an IgG1 immunoglobulin was fused with the Fab portion of the murine $14 \mathrm{G} 2 \mathrm{a}$ antibody to produce this chimeric mouse/human antibody against GD2 (Figure 2). In vitro, ch14.18 mediated ADCC 50-100 fold more efficiently than $14 . \mathrm{G} 2 \mathrm{~A},{ }^{57}$ and was tested extensively in the clinic as a single agent and with cytokines GM-CSF and IL2. ${ }^{58-67}$ In 2010, Yu et al of the Children's Oncology Group (COG) reported on a randomized Phase 3 trial of ch14.18, in newly diagnosed children with high-risk NB who had achieved at least a partial response to induction chemotherapy. Following myeloablative chemotherapy, in a state of minimal residual disease, patients then received dinutuximab qd x 4 every 28 days given with either GMCSF (course 1, 3 and 5) or interleukin-2 (IL-2; course 2 and 4 ) as well as monthly isotretinoin. ${ }^{25}$ This immunotherapeutic combination resulted in a dramatic improvement in 2-year event-free survival, compared to the group who received isotretinoin alone $(66 \%$ vs $46 \%$ at 2 -yrs, respectively; $\mathrm{P}=0.01$ ). These data led to NB becoming the first pediatric solid tumor with an approved immunotherapy, using this mAb, now called dinutuximab (Unituxin ${ }^{\circledR}$ ), in combination with cytokines and isotretinoin (https://www. cancer.gov/news-events/cancer-currents-blog/2015/dinutux imab-neuroblastoma). These excellent results with dinutuximab provide promise that further improvements in immunotherapy will enhance outcome in children with NB. For example, the use of dinutuximab in combination with irinotecan and temozolomide has shown significant activity in patients with relapsed/refractory disease with objective responses in $22 / 53$ patients $(41.5 \%$; $95 \%$ CI $28.2-54.8 \%) .^{68,69}$ Ongoing studies extending the evaluation of dinutuximab in neuroblastoma include COG studies ANBL1821, a randomized Phase II study of irinotecan, temozolomide and dinutuximab with/without eflornithine (NCT03794349), ANBL07P1, a pilot study in newly diagnosed children adding dinutuximab to induction chemotherapy (NCT03786783) and ANBL19P1, a Pilot study of dinutuximab, GM-CSF and isotretinoin with irinotecan and temozolomide in the postconsolidation setting (NCT04385277). The NANT 
Table I Clinical Trials of Anti-GD2 Monoclonal Antibodies

\begin{tabular}{|c|c|c|c|c|c|c|}
\hline Antibody & & Characteristics & Other Key Features & Dosage & Common Toxicities & References \\
\hline \multicolumn{7}{|c|}{ Approved } \\
\hline $\begin{array}{l}\text { chl4.18 } \\
\text { (Dinutuximab, } \\
\text { Unituxan }{ }^{\circledR} \text { ) }\end{array}$ & $\begin{array}{l}\text { Approved } \\
\text { by FDA* }\end{array}$ & $\begin{array}{l}\text { Murine-human } \\
\text { IgGI mAb } \\
\text { produced in } \\
\text { murine myeloma } \\
\text { SP } 2 / 0 \text { cells }\end{array}$ & \multirow[t]{2}{*}{$\begin{array}{l}\text { Only difference between } \\
\text { dinutuximab and dinutuximab } \\
\text { beta is the glycosylation } \\
\text { pattern which is a result of } \\
\text { manufacture in different cell } \\
\text { lines }\end{array}$} & $\begin{array}{l}17.5 \mathrm{mg} / \mathrm{m}^{2} / \\
\mathrm{qd} \times 4\end{array}$ & $\begin{array}{l}\text { Neuropathic pain, capillary } \\
\text { leak, hypotension, } \\
\text { hypersensitivity reactions }\end{array}$ & [25] \\
\hline $\begin{array}{l}\text { chl4.18/CHO } \\
\text { (dinutuximab } \\
\text { beta; } \\
\text { Qarziba }{ }^{\circledR} \text { ) }\end{array}$ & $\begin{array}{l}\text { Approved } \\
\text { by EMA** }\end{array}$ & $\begin{array}{l}\text { Murine-human } \\
\text { lgGI mAb made } \\
\text { in } \mathrm{CHO} \text { cells }\end{array}$ & & $\begin{array}{l}100 \mathrm{mg} / \mathrm{m}^{2} / \\
\text { course: } \\
\text { either } \\
10 \mathrm{mg} / \mathrm{m}^{2} / \mathrm{d} \\
\times 10 \mathrm{~d} \mathrm{or} \\
20 \mathrm{mg} / \mathrm{m}^{2} / \mathrm{d} \\
\times 5 \mathrm{~d}\end{array}$ & $\begin{array}{l}\text { Neuropathic pain, capillary } \\
\text { leak, hypersensitivity } \\
\text { reactions, "impaired general } \\
\text { condition" }\end{array}$ & {$[73,74]$} \\
\hline $\begin{array}{l}\text { Hu3F8 } \\
\text { (Naxitumab) }\end{array}$ & $\begin{array}{l}\text { Approved } \\
\text { by FDA }\end{array}$ & $\begin{array}{l}\text { Humanized 3F8 } \\
\text { mAb }\end{array}$ & $\begin{array}{l}\text { IgGI humanized form of } \\
\text { m3F8 }\end{array}$ & $\begin{array}{l}0.9-9.6 \mathrm{mg} / \\
\mathrm{kg} / \mathrm{cycle}[\mathrm{M} \text {, } \\
\text { W,Fri q mo] } \\
(27-288 \mathrm{mg} / \\
\left.\mathrm{m}^{2}\right)\end{array}$ & Pain, urticaria and cough & {$[81,82]$} \\
\hline \multicolumn{7}{|c|}{ Investigational } \\
\hline $3 F 8$ & & Murine $\lg \mathrm{G} 3 \mathrm{mAb}$ & HAMA interferes with activity & $\begin{array}{l}5-100 \mathrm{mg} / \\
\mathrm{m}^{2} \text { iv over } \\
8 \mathrm{hrs} \times 2-4 \mathrm{~d}\end{array}$ & $\begin{array}{l}\text { Pain, focal urticaria, } \\
\text { hypertension }\end{array}$ & {$[21,55]$} \\
\hline I4.G2a & & $\begin{array}{l}\text { Murine } \lg G 2 a \\
\mathrm{mAb}\end{array}$ & $\begin{array}{l}\text { HAMA interferes with } \\
\text { activity } 157\end{array}$ & $\begin{array}{l}50-400 \mathrm{mg} / \\
\mathrm{m}^{2} \mathrm{ci} \times 5-10 \\
\mathrm{~d}\end{array}$ & $\begin{array}{l}\text { Neuropathic pain, } \\
\text { hypertension, fever, rash, } \\
\text { urticaria, pruritus, } \\
\text { paresthesia, weakness, } \\
\text { chronic refractory postural } \\
\text { hypotension }\end{array}$ & {$[23,53]$} \\
\hline Hul4.18K322A & & $\begin{array}{l}\text { Humanized } \mid g G I \\
\text { mAb with point } \\
\text { mutation } \\
\text { designed to } \\
\text { decrease } \\
\text { complement } \\
\text { activation }\end{array}$ & $\begin{array}{l}\text { ADCC activity may be more } \\
\text { robust than dinutuximab and } \\
\text { may cause less pain }\end{array}$ & $\begin{array}{l}2-70 \mathrm{mg} / \mathrm{m}^{2} \\
\mathrm{qd} \times 4\end{array}$ & $\begin{array}{l}\text { Neuropathic pain, cough, } \\
\text { asthenia, sensory } \\
\text { neuropathy, anorexia, } \\
\text { serum sickness, } \\
\text { hypertensive } \\
\text { encephalopathy }\end{array}$ & {$[39,77,78]$} \\
\hline \multicolumn{6}{|c|}{ Antibody Conjugates } & \\
\hline$|3| \mid-3 F 8$ & & $\begin{array}{l}\text { Murine } \mathrm{mAb} \\
\text { attached to }{ }^{|3|} \mid\end{array}$ & & $\mathrm{I}-20 \mathrm{mCi}$ & $\begin{array}{l}\text { Headache, fever and } \\
\text { vomiting }\end{array}$ & {$[11,158]$} \\
\hline
\end{tabular}

(Continued) 
Table I (Continued).

\begin{tabular}{|l|l|l|l|l|l|l|}
\hline Antibody & & Characteristics & Other Key Features & Dosage & Common Toxicities & References \\
\hline Hul4.8-IL-2 & & $\begin{array}{l}\text { Humanized I4.18 } \\
\text { attached to } \\
\text { Interleukin-2 }\end{array}$ & $\begin{array}{l}\text { Patients with disease } \\
\text { evaluable only by MIBG and/ } \\
\text { or BM histology had better } \\
\text { responses than those with } \\
\text { bulky disease }\end{array}$ & $\begin{array}{l}\text { 2-14.4 mg/ } \\
\mathrm{m}^{2} / \mathrm{d}\end{array}$ & $\begin{array}{l}\text { Hypotension, capillary leak, } \\
\text { fever, hypoxia, rigors, } \\
\text { blurred vision, allergic } \\
\text { reaction, elevated } \\
\text { transaminases and bilirubin, } \\
\text { neutropenia, } \\
\text { thrombocytopenia }\end{array}$ \\
\hline
\end{tabular}

Notes: *https://www.accessdata.fda.gov/drugsatfda_docs/nda/2015/I255I6Orig/s000TOC.cfm; indicated, in combination with granulocyte-macrophage colony-stimulating factor (GM-CSF), interleukin-2 (IL-2), and I3-cis-retinoic acid (RA), for the treatment of pediatric patients with high-risk neuroblastoma who achieve at least a partial response to prior first-line multiagent, multimodality therapy. ${ }^{25} * *$ https://www.ema.europa.eu/en/medicines/human/EPAR/qarziba; indicated for the treatment of high-risk neuroblastoma in patients aged 12 months and above, who have previously received induction chemotherapy and achieved at least a partial response, followed by myeloablative therapy and stem cell transplantation, as well as patients with history of relapsed or refractory neuroblastoma, with or without residual disease. ${ }^{\dagger}$ https://www. fda.gov/drugs/drug-approvals-and-databases/fda-grants-accelerated-approval-naxitamab-high-risk-neuroblastoma-bone-or-bone-marrow.

Abbreviations: qd, daily; d, day; ADCC, antibody-dependent cell-mediated cytotoxicity; HAMA, human anti-mouse antibodies.

consortium is also evaluating dinutuximab in combination with Vorinostat and ${ }^{131}$ I-MIBG (NCT03332667).

\section{Dinutuximab-Beta}

A biosimilar to dinutuximab, ch14.18/CHO, now called dinutuximab beta $\left(\right.$ Qarziba $\left.^{\circledR}\right)$, has been approved by the
European Medicines Agency. ${ }^{70}$ Ch14.18 was recloned in Chinese hamster ovary $(\mathrm{CHO})$ cells $^{26}$ and shown to have comparable pharmacokinetics and safety profile to dinutuximab. ${ }^{71}$ The International Society of Pediatric Oncology Europe Neuroblastoma group (SIOPEN) was evaluating dinutuximab beta in a randomized trial (HR-NBL1),
A

A

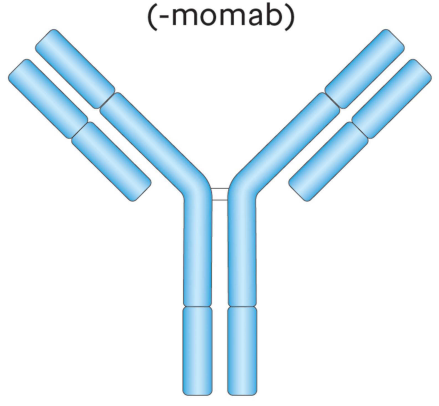

D

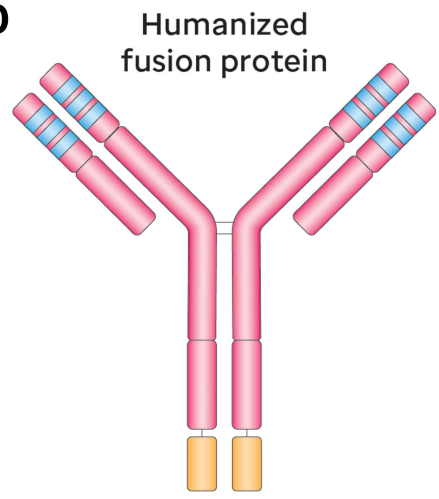

B

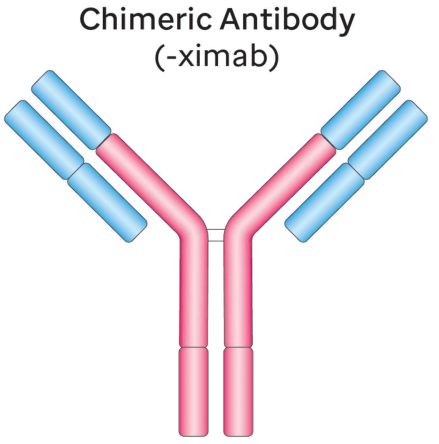

E

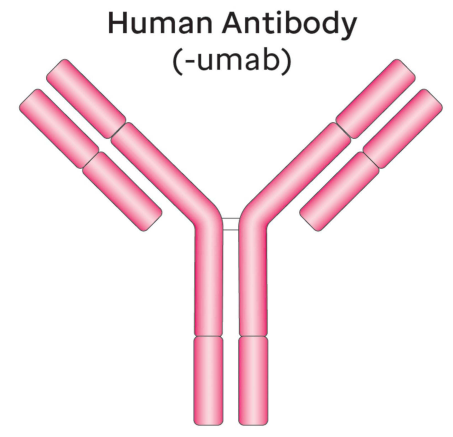

\section{Humanized Antibody}

(-zumab)

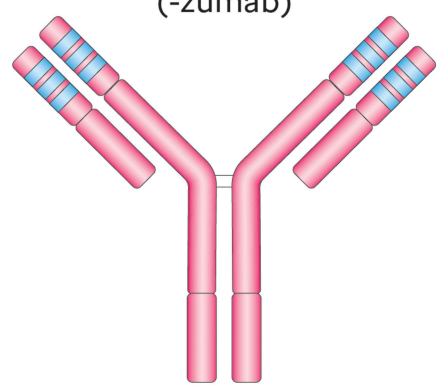

Murine $\square$ Human $\square \mathrm{L}$-2

Figure 2 Schematic diagram of anti-GD2 monoclonal antibodies and naming schema based on structure. A-fully murine monoclonal antibody, B-chimeric monoclonal antibody, C-humanized monoclonal antibody, D-humanized monoclononal antibody with addition of interleukin-2, and E-fully human monoclonal antibody. Suffix of murine mAbs -momab, suffix of chimeric antibodies - ximab; suffix of humanized antibodies - zumab; suffix of human antibodies - umab. 
comparing it to isotretinoin alone, until results of COG's trial with dinutuximab ${ }^{25}$ became available, after which accrual was halted and the design was modified to investigate the role of dinutuximab beta with/without IL-2. ${ }^{72,73}$ This randomized study concluded that there were higher rates of fever, pain, allergic reactions and other toxicities when dinutuximab beta was combined with IL-2. Additionally there was no evidence that IL-2 improved outcomes. ${ }^{73}$ Based on these data, IL-2 is no longer used with dinutuximab in the ongoing COG trial for children with newly diagnosed high-risk NB (ANBL1531; NCT03126916).

To improve the tolerability of dinutuximab beta, a 10day continuous infusion schedule was developed. Fiftythree patients received $10 \mathrm{mg} / \mathrm{m}^{2} /$ day of dinutuximab beta by $24-\mathrm{hr}$ continuous infusion daily x 10 with $6 \times 10^{6} \mathrm{IU} / \mathrm{m}^{2}$ IL-2 (d1-5; 8-12) with oral isotretinoin. They found low pain scores and reduced IV morphine usage with subsequent cycles, allowing $\mathrm{mAb}$ infusions as outpatients in more than $90 \%$ of cycles after the first course. ${ }^{74}$ This longterm infusion schedule of dinutuximab beta is being evaluated further in newly diagnosed children by the SIOPEN group, in combination with/without $3 \times 10^{6} \mathrm{IU} / \mathrm{m}^{2}$ IL-2 (d1-5; 8-12), which is $50 \%$ of the IL-2 dose used in previous randomization (NCT01704716). ${ }^{73}$ Dinutuximab beta is also being further evaluated by the Innovative Therapies for Children with Cancer in Europe consortium in a randomized trial in children with relapsed/refractory neuroblastoma in combination with chemotherapy (BEACON-Immuno) and in another consortium, in combination with nivolumab and ${ }^{131}$ I-MIBG (NCT02914405).

\section{Humanized Anti-GD2 Antibodies Hul4.18K322A}

Humanization of murine mAbs makes them less immunogenic and more tolerable. ${ }^{75}$ This $\mathrm{mAb}$ contains fully human amino acid sequences for the IgG1 kappa light and heavy chains, combined with the complementaritydetermining regions of antigen binding of the murine 14.18. The result is an approximately $98 \%$ human $\mathrm{mAb}$. Additionally, a single point mutation was introduced to decrease complement activation $(\mathrm{K} 322 \mathrm{~A})^{76}$ in an attempt to ameliorate the severe neuropathic pain $^{39}$ seen with all anti-GD2 mAbs (see Table 1). As a single agent hu14.18K322A was given in doses of $2-70 \mathrm{mg} / \mathrm{m}^{2} / \mathrm{d} \mathrm{x} \mathrm{4}$, q 28 days. Toxicities were similar to other anti-GD2 mAbs, including significant pain, especially with the first course. $^{77}$ However, in a retrospective review comparing pain outcomes of nine newly diagnosed children treated with dinutuximab $\left(25 \mathrm{mg} / \mathrm{m}^{2} / \mathrm{d} \times 4\right.$, given over 10 hours daily $x$ 4) to nineteen patients with recurrent NB being treated on the Phase 1 trial of hu14.18K322A (dosages of 40, 50, 60 or $70 \mathrm{mg} / \mathrm{m}^{2} / \mathrm{d} \times$ 4, given over 4-hrs daily $\mathrm{x} 4),{ }^{77}$ those receiving hu14.18K322A had lower opioid requirements than the nine who were receiving dinutuximab. ${ }^{78}$ Furthermore, the differences in median opioid requirements for the overall course were significantly lower $(1.57 \mathrm{vs} 2.41 \mathrm{mg} / \mathrm{kg} ; \mathrm{p}=0.019){ }^{78}$ This reduction in opioid support for those children receiving hu14.18K322A was despite receiving $\mathrm{mAb}$ doses more than 1.5 times the dose of dinutuximab, strongly suggesting that the K322A mutation was effective in reducing, but not eliminating the pain experienced by all anti-GD2 mAbs. Hu14.18K322A was combined with each of six courses of induction chemotherapy in a Phase II study involving 64 patients 19 years or younger with newly diagnosed high-risk NB. Each course of "chemoimmunotherapy" was followed by daily sq GM-CSF and 1 x 10${ }^{6} \mathrm{IU} / \mathrm{m}^{2}$ of IL-2 every other day for six doses. Some patients received an additional course of hu14.18K322A along with infusion of parental natural killer (NK) cells during the consolidation phase of treatment. Following recovery from consolidation, minimal residual disease was treated with GM-CSF, IL-2 and isotretinoin, identical to $\mathrm{Yu}$ et $\mathrm{al}^{25}$ with the substitution of hu14.18K322A for dinutuximab. ${ }^{79}$ In this single center Phase II trial, adding hu14.18K322A to induction chemotherapy produced early partial response (PR) or better in most patients, resulted in no progressions during induction, improved Curie Scores ${ }^{80}$ at the end of induction, and yielded an encouraging 2-year event-free survival (EFS) of $82.6 \% \quad(95 \% \quad \mathrm{CI}$, $70.1-90.3 \%){ }^{79}$ These data supported the development of a multi-institutional pilot study of dinutuximab given with induction chemotherapy by the COG (ANBL07P1; NCT03786783) which has just completed accrual.

\section{Hu3F8}

To circumvent the problem of HAMA development which accelerates antibody clearance, compromises efficacy and in some patients prevents retreatment, a humanized IgG1 form of the murine anti-GD2 mAb 3F8 (Hu3F8) was created. $^{81}$ Now called naxitamab (DANYELZA ${ }^{\circledR}$ ), in a Phase I trial, 57 patients were treated in the outpatient setting. Cohorts of 3 to 6 patients per dose level were enrolled. Naxitamab was given in doses from 0.9 to $9.6 \mathrm{mg} / \mathrm{kg} /$ cycle by 30 -minute IV infusion on Monday, 
Wednesday, and Friday as well as GM-CSF, sq from day -5 through the last naxitamab infusion. As with other antiGD2 mAbs, manageable neuropathic pain was seen in most patients. ${ }^{82}$ Humanized 3F8, (naxitamab), was granted Breakthrough Therapy designation in August of 2018 for use with GM-CSF in patients refractory to initial therapy or with incomplete response to salvage therapy in patients older than 12 months with persistent, refractory disease limited to bone marrow with or without evidence of concurrent bone involvement (http://www.onclive.com/view/ fda-approval-sought-for-naxitamab-in-neuroblastoma).

This was followed on November 25, 2020 with accelerated approval, again in combination with GM-CSF for patients older than 1 year with refractory or relapsed high-risk neuroblastoma limited to bone or bone marrow who had achieved at least stable disease to prior therapy. This approval was based on the results of two single-arm trials NCT03363373 and NCT01757626 in which patients received $3 \mathrm{mg} / \mathrm{kg}$ naxitamab IV on days 1,3 and 5 every 4-weeks in combination with SQ GM-CSF from day -4 to $+5\left(250 \mu \mathrm{g} / \mathrm{m}^{2} / \mathrm{d}, \mathrm{d}-4\right.$ to 0 and then $500 \mu \mathrm{g} / \mathrm{m}^{2} / \mathrm{d}, \mathrm{d}+1$ to $+5)$. Of 22 patients treated on NCT03363373 the objective response rate (ORR) was 45\% (95\% CI: 24-68\%). Responses lasted 6 months or longer in $23 \%$. Of 38 patients treated on NCT01757626, 34\% had a response (95\% CI: 20-50\%) and 23\% had responses lasting 6 months or more (https://www.fda.gov/drugs/drugapprovals-and-databases/fda-grants-accelerated-approvalnaxitamab-high-risk-neuroblastoma-bone-or-bone-

marrow). There is an international Phase 3 randomized trial (NCT04560166) in children with primary refractory disease or in first relapse with irinotecan/temozolomide \pm naxitamab that is soon to open.

\section{Pharmacokinetics and Pharmacodynamics of Anti-GD2 Monoclonal Antibodies}

As previously noted, these mAbs exert their effects by both ADCC and CDC to varying degrees, depending on the specific antibody. The determinants of mAb pharmacokinetics and pharmacodynamics are dependent on multiple factors including: distribution and density of the target antigen, binding affinity to the antigen, glycosylation pattern of the antibody, immunogenicity of the $\mathrm{mAb}$, rate of antibody penetration into a tumor, and effector cell number and function, among others. ${ }^{83-87}$ Although the most effective dose is unknown, dinutuximab beta has been shown to be active at concentrations $>1 \mu \mathrm{g} / \mathrm{mL}^{26,88}$ Also, as previously noted, the major problem with administration of these antibodies is the induction of severe neuropathic pain, which has limited the dosage that can be given.

There are several different doses and schedules of the various anti-GD2 mAbs currently in use. Dinutuximab is given at a dose of $17.5 \mathrm{mg} / \mathrm{m}^{2} /$ day as a 10 to 20 hour infusion, daily $\times 4^{25}$ In an attempt to ameliorate pain, dinutuximab beta is proceeding with a $10 \mathrm{mg} / \mathrm{m}^{2} /$ day dose by continuous infusion x 10 days. ${ }^{89}$ The humanized antibody naxitamab is given at $3 \mathrm{mg} / \mathrm{kg}$ day by 30 -minute infusion on M-W-Fri, while hu14.18K322A is given at $40 \mathrm{mg} / \mathrm{m} 2 /$ day by 4-hour infusion daily $\mathrm{x} 4$. Humanization has improved the tolerance, but not eliminated pain. The fact that pain resolves shortly after the $\mathrm{mAb}$ infusion is stopped, while the $\mathrm{mAb}$ still persists in the circulation suggests that pain may be related to doseinfusion rate rather that AUC. ${ }^{90}$ A detailed review of the pharmacokinetic/pharmacodynamic parameters of these antibodies is beyond the scope of this review. Optimizing the regimen and dose to maximize tolerability and response still needs some work.

\section{Anti-GD2 Antibody Conjugates ${ }^{13 \mid} \mid-3 F 8$}

${ }^{131} \mathrm{I}-3 \mathrm{~F} 8$ has demonstrated specific and sensitive imaging of metastatic $\mathrm{NB}^{91}$ as have three other anti-GD2 mAbs ${ }^{131} \mathrm{I}-14 \mathrm{G} 2 \mathrm{a},{ }^{23} 99 \mathrm{mTc}-\mathrm{ch} 14.18^{92}$ and $\mathrm{Cu}-\mathrm{p}-\mathrm{NH}_{2}-\mathrm{Bn}-\mathrm{DOTA}$ -hu14.18K322A. ${ }^{93}$ However ${ }^{131} \mathrm{I}-3 \mathrm{~F} 8$ is the only one that has been used for radioimmunotherapy of patients. ${ }^{94,95}$ The addition of ${ }^{131} \mathrm{I}-3 \mathrm{~F} 8$ to a multimodality treatment for newly diagnosed children with high-risk NB did not improve their progression free or overall survival, compared to those who did not receive ${ }^{131} \mathrm{I}-3 \mathrm{~F} 8 .^{50,95}$

\section{Hul4.18-IL-2}

Interleukin-2 (IL-2) improves the ability of effector cells to kill neuroblasts ${ }^{96,97}$ but has significant systemic side effects. ${ }^{98}$ The immunocytokine hu14.18-IL-2 was created to augment the antitumor effect of hu14.18 with IL- $2^{99}$ and at the same time limit the toxicity of systemic administration of IL-2. ${ }^{100}$ In a Phase I trial hu14.18-IL-2 was given to 27 children with recurrent/refractory NB and one with melanoma, IV over 4 hours qd x 3 at various dose levels. Three patients had evidence of tumor responses. ${ }^{101}$ In a subsequent Phase II study, patients were stratified into those with measurable disease (stratum 1; $\mathrm{n}=13$ ) and those with evaluable disease by bone marrow histology 
and/or ${ }^{131}$ I-metaiodobenzylguanidine (MIBG) scintigraphy (stratum 2; $\mathrm{n}=23$ ). Those with bulky disease (stratum 1) had no responses while $5 / 23$ patients on stratum 2 had marrow CRs. ${ }^{102}$ On the whole, adverse events were similar to those reported for other anti-GD2 mAbs when given with IL-2. Three patients discontinued treatment because of toxicity, two with acute vascular leak \pm hypotension and one with a grade 4 allergic reaction. ${ }^{102}$ Thus this hu14.18IL-2 conjugate did not seem to significantly improve the adverse event profile of hu14.18.

\section{Other Antibody Targets in Neuroblastoma O-Acetyl-GD2}

The O-acetyl derivative of the ganglioside GD2 is expressed on neuroblasts but not on peripheral nerves. ${ }^{103}$ A chimeric O-acetyl anti-GD2 mAb, c.8B6, has been shown to kill neuroblastoma cells without inducing allodynia in an animal model and offers promise that it may be better tolerated than dinutuximab. ${ }^{104,105}$ This antibody has not yet been clinically evaluated.

\section{B7-H3 (CD276)}

This is a membrane protein involved in the regulation of $\mathrm{T}$ and NK cells and is overexpressed on many solid tumors, including neuroblastoma. ${ }^{106-108}$ Expression on a neuroblast cell line protected neuroblasts from NKcell killing ${ }^{106}$ and overexpression on tumors often correlates with faster tumor progression and poor outcome. ${ }^{109}$ Omburtamab (8H9), a murine antibody that recognized $\mathrm{B} 7-\mathrm{H} 3,{ }^{110,111}$ has been linked to ${ }^{131}$ I (Burtomab) and used to treat children with Central Nervous System NB. In a phase 1 study, 80 patients were treated with burtomab in combination with intraventricular compartmental chemotherapy with irinotecan, temozolomide and carboplatin. Improvement on imaging was seen in $36 \%$ of children with measurable disease with a median duration of response of 49 weeks (range, 2.6 to 586 weeks). ${ }^{10,112,113}$ Based on these data burtomab was granted Breakthrough Therapy designation for metastatic NB (https://www.cancertherapyadvi sor.com/home/cancer-topics/pediatric-cancer/burtomabgranted-breakthrough-therapy-designation-for-metastatic -neuroblastoma/). A humanized anti-B7-H3 mAb, enoblituzumab, has been evaluated in a Phase I trial in children with various solid tumors, including NB [NCT02982941]. Results are not yet available. ${ }^{114}$

\section{ALK (Anaplastic Lymphoma Kinase)}

Mutations of ALK are observed in about $8 \%$ of all neuroblastomas ${ }^{115}$ and small molecule tyrosine kinase inhibitors of ALK are being used clinically in these patients [NCT03126916]. The native ALK protein is expressed on the majority of NB cells and not on normal cells, ${ }^{116}$ making treatment with an antibody targeting this protein a possibility. In human derived NB cell lines an ALK antibody inhibits growth in the absence of immune effector cells and is also able to mediate ADCC. ${ }^{116}$ AntiALK antibodies are not yet available for clinical testing.

\section{PD-I/PD-LI (Programmed Cell Death- I; Programmed Death-Ligand I)}

PD-1 and its ligands, PD-L1 and PD-L2, are molecules involved in the regulation of the immune system and part of multiple pathways called immune checkpoint pathways. ${ }^{12}$ Several cancers, including NB, ${ }^{117}$ make use of these pathways to inhibit tumor cell killing by immune effector cells. In a preclinical model of NB, when treated with dinutuximab beta, PD-L1 expression on neuroblasts was upregulated. When a murine anti-PD-1 mAb was combined with dinutuximab beta a synergistic antitumor response was seen. ${ }^{118}$ These data prompted the use of nivolumab, an antibody specific for PD-1, in combination with dinutuximab beta for the treatment of two heavily pretreated refractory patients, leading to a $\mathrm{CR}$ in one and VGPR in another. ${ }^{119}$ This report suggests that immune checkpoint inhibitors combined with anti-GD2 mAbs may be a promising approach to treat NB.

\section{GPC2 (Glycosylphosphatidylinositol Anchored Signaling Co-Receptor Glypican 2)}

Glypicans are a group of cell-surface glycoproteins linked to heparan sulfate glycosaminoglycan chains and regulate a number of growth and survival functions during embryogenesis. ${ }^{120}$ GPC2 is expressed at high levels on most $\mathrm{NB}$, but not on normal tissues and is required for neuroblast cell proliferation. ${ }^{121}$ An antibody against GPC2 conjugated to pyrrolobenzodiazepine, a DNA crosslinking agent, induced cytotoxicity, in seven human NB cell lines. ${ }^{121}$ These data suggest that GPC2 may be 
a promising new target for an anti-GPC2 mAb antibody drug conjugate. ${ }^{122}$

\section{CD47}

Integrin-associated protein (IAP) or CD47 is a transmembrane glycoprotein that is expressed on the surface of many types of cancer cells, ${ }^{123}$ including NB. ${ }^{124}$ It is an immune checkpoint on macrophages that functions as a "don't eat me" signal and has been co-opted by many types of cancer to prevent tumor cell killing. ${ }^{123,125,126}$ Paraffin embedded tumor tissues of 66 NB patients were tested for expression of CD47 and 28/ $66(42.4 \%)$ were positive, significantly more of these patients were high-risk, compared to low risk $(\mathrm{P}=$ 0.049). ${ }^{124}$ Since macrophages frequently infiltrate metastatic NB tumors ${ }^{127}$ and since CD47 is frequently expressed on high-risk tumors, the combination of dinutuximab with an anti-CD47 antibody was evaluated in pediatric xenograft models of NB and the combination was found to be synergistic. ${ }^{128}$ This combination will soon be tested in children. ${ }^{128}$

\section{Bispecific Monoclonal Antibodies (bsAbs)}

Bispecific antibodies are constructed with two different antigen-binding sites ${ }^{129}$ and for NB have been used to redirect activated T-cells to GD2 expressing neuroblast cell lines. ${ }^{130}$ These data supported the development of a clinical trial using the humanized 3F8 anti-GD2 mAb combined with CD3 (Hu3F8-BsAb; Nivatrotamab) which is currently recruiting patients [NCT03860207]. Another bsAb, coupling an anti-GD2 antibody with a B7-H3 antibody has been developed with the goal of limiting offtarget binding to GD2+/B7-H3 negative cells and reducing neuropathic pain. ${ }^{131}$ This bsAb, INV721, binds to tumors that express both GD2 and B7H3 but minimally to cells that do not express both antigens and is capable of ADCC. ${ }^{132}$

\section{Discussion}

Despite intensive multimodal therapy, many children with high-risk neuroblastoma still have poor outcomes. GD2, because of its consistent expression on neuroblasts, has been targeted by several different mAbs to improve the outcome of these patients (Table 1). As previously described, the use of dinutuximab with GM-CSF, IL-2 and isotretinoin, has dramatically improved the outcome of these patients leading to the first approved immunotherapy for children with solid tumors. ${ }^{25}$ Although these results are very promising, significant challenges remain to optimize these results for more children with this aggressive and deadly cancer. Significant toxic effects of dinutuximab included pain, hypersensitivity reactions, capillary leak and hypotension. ${ }^{25}$ Next generation antibodies were humanized (hu14.18K322A), or fully human (naxitamab) to improve tolerability and reduce the development of neutralizing antibodies. $\mathrm{Hu} 14.18 \mathrm{~K} 322 \mathrm{~A}$ was further modified to reduce complement activation, ${ }^{76}$ to ameliorate pain, an on-target, offtumor effect of antibody binding to peripheral nerves and activating complement. ${ }^{39}$ Although this modification appears to improve the tolerability of hu14.18K $322 \mathrm{~A}$, when compared to dinutuximab, ${ }^{78}$ this is not the whole answer. Is it possible that targeting the O-acetyl derivative of GD2, which is expressed on neuroblasts but not on peripheral nerves will alleviate this problem? Antibodies to this target are not yet available for clinical use. The humanization of hu14.18K322A has allowed significant dose escalation (40 mg/m $/ \mathrm{m}^{2}$ dose), ${ }^{79}$ when compared to dinutuximab $\left(17.5 \mathrm{mg} / \mathrm{m}^{2} /\right.$ dose $)$ and the fully human naxitamab is able to be administered in an outpatient setting. ${ }^{82}$ Another structural modification to enhance ADCC is incorporated in the production of hu14.18K $322 \mathrm{~A}$, and that is it is produced in a cell line that results in decreased fucosylation. Absence of fucose can improve antibody affinity to effector cells by up to 50-fold. ${ }^{133,134}$

Another augmentation to treatment with anti-GD2 mAbs has been to add cytokines such as GM-CSF ${ }^{42}$ and interleukin-2, ${ }^{135}$ because of their ability to enhance ADCC. Recent data have cast doubt on the added value of IL-2 because of significant added toxicities ${ }^{73}$ and its possible role in suppression of anti-tumor immune response $^{136}$ through induction of regulatory $\mathrm{T}$ cells. ${ }^{137}$ It is possible that other cytokines such as Interleukin$15^{138}$ or IL-2 $1^{139}$ will further enhance the effectiveness of anti-GD2 mAbs, without the significant toxicities of IL-2.

The initial evaluation of dinutuximab focused on treatment of patients after recovery from consolidation, in a state of minimal residual disease. This is because traditionally chemotherapy has been thought to be too immunosuppressive to combine with monoclonal antibodies. However recent studies suggest, even in the setting of "bulky" solid tumors, the combination of chemotherapy 
with monoclonal antibodies can be synergistic. ${ }^{140-143}$ In other preclinical studies chemotherapy can increase the efficacy of immunotherapy by depleting immunosuppressor cells such as regulatory T-cells which are known to suppress NK cell-mediated immunotherapy, ${ }^{144-146}$ the presumed major effector cells of anti-GD2 mAb induced ADCC in neuroblastoma. ${ }^{24,147}$ Also chemotherapyinduced tumor cell death can trigger tumor antigen release, uptake by antigen processing cells and an enhanced antitumor immune response. ${ }^{140,145,148}$ For these reasons we combined hu14.18K322A with induction chemotherapy in newly diagnosed children with high-risk NB in a single institution pilot Phase II study. All patients had clinical benefit with a near doubling of early responses, compared to a group of patients who received identical chemotherapy without hu14.18K322A, improvement in Curie Scores and no progressions during induction. ${ }^{79}$ These results suggest that anti-GD2 mAbs can have significant activity in bulky disease if utilized with the "right" combinations. More work needs to be done to determine how best to integrate these antibodies into standard treatment. The impressive improvement in event free survival with the use of dinutuximab has provided a "proof of principle"149 for further refining therapy using antibodies to other targets such as those described above.

\section{Conclusion}

The use of the chimeric anti-GD2 mAb following consolidation in newly diagnosed children with high-risk disease has revolutionized the treatment of these patients. The resulting improvements in EFS has led to enthusiasm that optimization of antibody design, addition of additional cytokines to further enhance ADCC and or mAbs to other targets will lead to more cures with less toxicity. Vaccines or cellular therapies such as chimeric antigen receptor (CAR) T cells ${ }^{150-152}$ or adoptive NK cells, ${ }^{153-156}$ although beyond the scope of this review, could further improve the treatment of these challenging patients.

\section{Disclosure}

The author reports no conflicts of interest in this work.

\section{References}

1. Yoshida S, Kawaguchi H, Sato S, Ueda R, Furukawa K. An anti-GD2 monoclonal antibody enhances apoptotic effects of anti-cancer drugs against small cell lung cancer cells via JNK (c-Jun terminal kinase) activation. Jpn J Cancer Res. 2002;93(7):816-824. doi:10.1111/ j.1349-7006.2002.tb01324.x
2. Kowalczyk A, Gil M, Horwacik I, Odrowaz Z, Kozbor D, Rokita H. The GD2-specific 14G2a monoclonal antibody induces apoptosis and enhances cytotoxicity of chemotherapeutic drugs in IMR-32 human neuroblastoma cells. Cancer Lett. 2009;281 (2):171-182. doi:10.1016/j.canlet.2009.02.040

3. Doronin II, Vishnyakova PA, Kholodenko IV, et al. Ganglioside GD2 in reception and transduction of cell death signal in tumor cells. BMC Cancer. 2014;14:295. doi:10.1186/1471-2407-14-295

4. Weiner LM, Surana R, Wang S. Monoclonal antibodies: versatile platforms for cancer immunotherapy. Nat Rev Immunol. 2010;10 (5):317-327. doi:10.1038/nri2744

5. Shuptrine CW, Surana R, Weiner LM. Monoclonal antibodies for the treatment of cancer. Semin Cancer Biol. 2012;22(1):3-13. doi:10.1016/j.semcancer.2011.12.009

6. Dickson PV, Hamner JB, Sims TL, et al. Bevacizumab-induced transient remodeling of the vasculature in neuroblastoma xenografts results in improved delivery and efficacy of systemically administered chemotherapy. Clin Cancer Res. 2007;13 (13):3942-3950. doi:10.1158/1078-0432.CCR-07-0278

7. Sano R, Krytska K, Larmour CE, et al. An antibody-drug conjugate directed to the ALK receptor demonstrates efficacy in preclinical models of neuroblastoma. Sci Transl Med. 2019;11:483. doi:10.1126/scitranslmed.aau9732

8. Brown BS, Patanam T, Mobli K, et al. Etoposide-loaded immunoliposomes as active targeting agents for GD2-positive malignancies. Cancer Biol Ther. 2014;15(7):851-861. doi:10.41 $61 /$ cbt.28875

9. Tur MK, Sasse S, Stocker M, et al. An anti-GD2 single chain Fv selected by phage display and fused to Pseudomonas exotoxin A develops specific cytotoxic activity against neuroblastoma derived cell lines. Int J Mol Med. 2001;8(5):579-584. doi:10. 3892/ijmm.8.5.579

10. Kramer K, Kushner BH, Modak S, et al. Compartmental intrathecal radioimmunotherapy: results for treatment for metastatic CNS neuroblastoma. J Neurooncol. 2010;97(3):409-418. doi:10.1007/ s11060-009-0038-7

11. Kramer K, Humm JL, Souweidane MM, et al. Phase I study of targeted radioimmunotherapy for leptomeningeal cancers using intra-Ommaya 131-I-3F8. J Clin Oncol. 2007;25(34):54 65-5470. doi:10.1200/JCO.2007.11.1807

12. Pardoll DM. The blockade of immune checkpoints in cancer immunotherapy. Nat Rev Cancer. 2012;12(4):252-264. doi:10. $1038 / \mathrm{nrc} 3239$

13. Hoehner JC, Gestblom C, Hedborg F, Sandstedt B, Olsen L, Pahlman S. A developmental model of neuroblastoma: differentiating stroma-poor tumors' progress along an extra-adrenal chromaffin lineage. Lab Investig. 1996;75(5):659-675.

14. Maris JM, Hogarty MD, Bagatell R, Cohn SL. Neuroblastoma. Lancet. 2007;369(9579):2106-2120. doi:10.1016/S01406736(07)60983-0

15. Matthay KK, Maris JM, Schleiermacher G, et al. Neuroblastoma. Nat Rev Dis Primers. 2016;2:16078. doi:10.1038/nrdp.2016.78

16. Maris JM. The biologic basis for neuroblastoma heterogeneity and risk stratification. Curr Opin Pediatr. 2005;17(1):7-13. doi:10.1097/01.mop.0000150631.60571.89

17. Maris JM. Recent advances in neuroblastoma. $N$ Engl J Med. 2010;362(23):2202-2211. doi:10.1056/NEJMra0804577

18. Schultz LM, Majzner R, Davis KL, Mackall C. New developments in immunotherapy for pediatric solid tumors. Curr Opin Pediatr. 2018;30(1):30-39. doi:10.1097/MOP.0000000000000 564

19. Mujoo K, Cheresh DA, Yang HM, Reisfeld RA. Disialoganglioside GD2 on human neuroblastoma cells: target antigen for monoclonal antibody-mediated cytolysis and suppression of tumor growth. Cancer Res. 1987;47(4):10 98-1104. 
20. Wu ZL, Schwartz E, Seeger R, Ladisch S. Expression of GD2 ganglioside by untreated primary human neuroblastomas. Cancer Res. 1986;46(1):440-443.

21. Cheung NK, Lazarus H, Miraldi FD, et al. Ganglioside GD2 specific monoclonal antibody 3F8: a phase I study in patients with neuroblastoma and malignant melanoma. J Clin Oncol. 1987;5(9):1430-1440. doi:10.1200/JCO.1987.5.9.1430

22. Mujoo K, Kipps TJ, Yang HM, et al. Functional properties and effect on growth suppression of human neuroblastoma tumors by isotype switch variants of monoclonal antiganglioside GD2 antibody 14.18. Cancer Res. 1989;49(11):2857-2861.

23. Murray JL, Cunningham JE, Brewer H, et al. Phase I trial of murine monoclonal antibody 14G2a administered by prolonged intravenous infusion in patients with neuroectodermal tumors. J Clin Oncol. 1994;12(1):184-193. doi:10.1200/ JCO.1994.12.1.184

24. Barker E, Mueller BM, Handgretinger R, Herter M, Yu AL, Reisfeld RA. Effect of a chimeric anti-ganglioside GD2 antibody on cell-mediated lysis of human neuroblastoma cells. Cancer Res. 1991;51(1):144-149.

25. Yu AL, Gilman AL, Ozkaynak MF, et al. Anti-GD2 antibody with GM-CSF, interleukin-2, and isotretinoin for neuroblastoma. $N$ Engl J Med. 2010;363(14):1324-1334. doi:10.1056/ NEJMoa0911123

26. Zeng Y, Fest S, Kunert R, et al. Anti-neuroblastoma effect of ch14.18 antibody produced in CHO cells is mediated by NK-cells in mice. Mol Immunol. 2005;42(11):1311-1319. doi:10.1016/j. molimm.2004.12.018

27. Horta ZP, Goldberg JL, Sondel PM. Anti-GD2 mAbs and next-generation mAb-based agents for cancer therapy. Immunotherapy. 2016;8(9):1097-1117. doi:10.2217/imt-20160021

28. Alvarez-Rueda N, Leprieur S, Clemenceau B, et al. Binding activities and antitumor properties of a new mouse/human chimeric antibody specific for GD2 ganglioside antigen. Clin Cancer Res. 2007;13(18):5613s-5620s. doi:10.1158/1078-0432.CCR-071057

29. Nazha B, Inal C, Owonikoko TK. Disialoganglioside GD2 expression in solid tumors and role as a target for cancer therapy. Front Oncol. 2020;10:1000. doi:10.3389/fonc.20 20.01000

30. Cheung NK, Saarinen UM, Neely JE, Landmeier B, Donovan D, Coccia PF. Monoclonal antibodies to a glycolipid antigen on human neuroblastoma cells. Cancer Res. 1985;45(6):2642-2649.

31. Lammie G, Cheung N, Gerald W, Rosenblum M, Cordoncardo C. Ganglioside $\operatorname{gd}(2)$ expression in the human nervous-system and in neuroblastomas - an immunohistochemical study. Int J Oncol. 1993;3(5):909-915. doi:10.3892/ijo.3.5.909

32. Jin HJ, Nam HY, Bae YK, et al. GD2 expression is closely associated with neuronal differentiation of human umbilical cord blood-derived mesenchymal stem cells. Cell Mol Life Sci. 2010;67(11):1845-1858. doi:10.1007/s00018-0100292-z

33. Martinez C, Hofmann TJ, Marino R, Dominici M, Horwitz EM. Human bone marrow mesenchymal stromal cells express the neural ganglioside GD2: a novel surface marker for the identification of MSCs. Blood. 2007;109(10):4245-4248. doi:10.1182/ blood-2006-08-039347

34. Suzuki M, Cheung NK. Disialoganglioside GD2 as a therapeutic target for human diseases. Expert Opin Ther Targets. 2015;1-14

35. Cavdarli S, Groux-Degroote S, Delannoy P. Gangliosides: the double-edge sword of neuro-ectodermal derived tumors. Biomolecules. 2019;9(8):311. doi:10.3390/biom9080311

36. Navid F, Santana VM, Barfield RC. Anti-GD2 antibody therapy for GD2-expressing tumors. Curr Cancer Drug Targets. 2010;10 (2):200-209. doi:10.2174/156800910791054167
37. Cheresh DA, Pierschbacher MD, Herzig MA, Mujoo K Disialogangliosides GD2 and GD3 are involved in the attachment of human melanoma and neuroblastoma cells to extracellular matrix proteins. J Cell Biol. 1986;102(3):688-696. doi:10.1083/ jcb.102.3.688

38. Yuki N, Yamada M, Tagawa $\mathrm{Y}$, Takahashi $\mathrm{H}$, Handa $\mathrm{S}$. Pathogenesis of the neurotoxicity caused by anti-GD2 antibody therapy. J Neurol Sci. 1997;149(2):127-130. doi:10.1016/S0022510X(97)05390-2

39. Sorkin LS, Otto M, Baldwin WM, et al. Anti-GD(2) with an FC point mutation reduces complement fixation and decreases antibody-induced allodynia. Pain. 2010;149(1):135-142. doi:10.1016/j.pain.2010.01.024

40. Baluna R, Vitetta ES. Vascular leak syndrome: a side effect of immunotherapy. Immunopharmacology. 1997;37(2-3):117-132. doi:10.1016/S0162-3109(97)00041-6

41. Matthay KK. Interleukin 2 plus anti-GD2 immunotherapy: helpful or harmful? Lancet Oncol. 2018;19(12):1549-1551. doi:10.1016/S1470-2045(18)30627-2

42. Kushner BH, Cheung NK. GM-CSF enhances 3F8 monoclonal antibody-dependent cellular cytotoxicity against human melanoma and neuroblastoma. Blood. 1989;73(7):1936-1941. doi:10.1182/blood.V73.7.1936.1936

43. Cheung NK, Kushner BH, Cheung IY, et al. Anti-G(D2) antibody treatment of minimal residual stage 4 neuroblastoma diagnosed at more than 1 year of age. J Clin Oncol. 1998;16(9):3053-3060. doi:10.1200/JCO.1998.16.9.3053

44. Kushner BH, Kramer K, Cheung NK. Phase II trial of the anti-G (D2) monoclonal antibody $3 \mathrm{~F} 8$ and granulocyte-macrophage colony-stimulating factor for neuroblastoma. J Clin Oncol. 2001;19(22):4189-4194. doi:10.1200/JCO.2001.19.22.4189

45. Cheung IY, Hsu K, Cheung NK. Activation of peripheral-blood granulocytes is strongly correlated with patient outcome after immunotherapy with anti-GD2 monoclonal antibody and granulocyte-macrophage colony-stimulating factor. J Clin Oncol. 2012;30(4):426-432. doi:10.1200/JCO.2011.37.6236

46. Cheung NK, Modak S. Oral (1->3),(1->4)-beta-D-glucan synergizes with antiganglioside GD2 monoclonal antibody $3 \mathrm{~F} 8$ in the therapy of neuroblastoma. Clin Cancer Res. 2002;8(5):1217-1223.

47. Cheung NK, Kushner BH, Yeh SD, Larson SM. 3F8 monoclonal antibody treatment of patients with stage 4 neuroblastoma: a phase II study. Int J Oncol. 1998;12(6):1299-1306. doi:10.3892/ijo.12.6.1299

48. Johnson E, Dean SM, Sondel PM. Antibody-based immunotherapy in high-risk neuroblastoma. Expert Rev Mol Med. 2007;9 (34):1-21. doi:10.1017/S1462399407000518

49. Cheung NK, Cheung IY, Kramer K, et al. Key role for myeloid cells: phase II results of anti-G(D2) antibody 3F8 plus granulocyte-macrophage colony-stimulating factor for chemoresistant osteomedullary neuroblastoma. Int J Cancer. 2014;135 (9):2199-2205

50. Cheung NK, Cheung IY, Kushner BH, et al. Murine anti-GD2 monoclonal antibody 3F8 combined with granulocyte-macrophage colony-stimulating factor and 13-cis-retinoic acid in high-risk patients with stage 4 neuroblastoma in first remission. J Clin Oncol. 2012;30 (26):3264-3270. doi:10.1200/JCO.2011.41.3807

51. Kushner BH, Ostrovnaya I, Cheung IY, et al. Prolonged progression-free survival after consolidating second or later remissions of neuroblastoma with anti-GD2 immunotherapy and isotretinoin: a prospective Phase II study. Oncoimmunology. 2015;4(7):e1016704. doi:10.1080/2162402X.2015.1016704

52. Cheung IY, Kushner BH, Modak S, Basu EM, Roberts SS, Cheung NV. Phase I trial of anti-GD2 monoclonal antibody hu3F8 plus GM-CSF: impact of body weight, immunogenicity and anti-GD2 response on pharmacokinetics and survival. Oncoimmunology. 2017;6(11):e1358331. doi:10.1080/2162402X. 2017.1358331 
53. Handgretinger R, Baader P, Dopfer R, et al. A phase I study of neuroblastoma with the anti-ganglioside GD2 antibody 14.G2a. Cancer Immunol Immunother. 1992;35(3):199-204. doi:10.1007/ BF01756188

54. Frost JD, Hank JA, Reaman GH, et al. A phase I/IB trial of murine monoclonal anti-GD2 antibody 14.G2a plus interleukin-2 in children with refractory neuroblastoma: a report of the Children's Cancer Group. Cancer. 1997;80(2):317-333. doi:10.1002/(SICI)10970142(19970715)80:2<317::AID-CNCR21>3.0.CO;2-W

55. Cheung NK, Cheung IY, Canete A, et al. Antibody response to murine anti-GD2 monoclonal antibodies: correlation with patient survival. Cancer Res. 1994;54(8):2228-2233.

56. Lu RM, Hwang YC, Liu IJ, et al. Development of therapeutic antibodies for the treatment of diseases. J Biomed Sci. 2020;27 (1):1.

57. Mueller BM, Romerdahl CA, Gillies SD, Reisfeld RA. Enhancement of antibody-dependent cytotoxicity with a chimeric anti-GD2 antibody. J Immunol. 1990;144(4):13 82-1386.

58. Handgretinger R, Anderson K, Lang P, et al. A phase I study of human/mouse chimeric antiganglioside GD2 antibody ch14.18 in patients with neuroblastoma. EurJ Cancer. 1995;31(2):261-267. doi:10.1016/0959-8049(94)00413-Y

59. Yu AL, Uttenreuther-Fischer MM, Huang CS, et al. Phase I trial of a human-mouse chimeric anti-disialoganglioside monoclonal antibody ch14.18 in patients with refractory neuroblastoma and osteosarcoma. J Clin Oncol. 1998;16(6):2169-2180. doi:10.1200/ JCO.1998.16.6.2169

60. Murray JL, Kleinerman ES, Jia SF, et al. Phase Ia/Ib trial of anti-GD2 chimeric monoclonal antibody 14.18 (ch14.18) and recombinant human granulocyte-macrophage colony-stimulating factor (rhGM-CSF) in metastatic melanoma. $J$ Immunother Emphasis Tumor Immunol. 1996;19(3):206-217. doi:10.1097/ 00002371-199605000-00005

61. Saleh MN, Khazaeli MB, Wheeler RH, et al. Phase I trial of the chimeric anti-GD2 monoclonal antibody ch14.18 in patients with malignant melanoma. Hum Antibodies Hybridomas. 1992;3 (1):19-24. doi:10.3233/HAB-1992-3104

62. Albertini MR, Gan J, Jaeger P, et al. Systemic interleukin-2 modulates the anti-idiotypic response to chimeric anti-GD2 antibody in patients with melanoma. $J$ Immunother Emphasis Tumor Immunol. 1996;19(4):278-295.

63. Albertini MR, Hank JA, Schiller JH, et al. Phase IB trial of chimeric antidisialoganglioside antibody plus interleukin 2 for melanoma patients. Clin Cancer Res. 1997;3(8):1277-1288.

64. Yu AL, Batova A, Alvarado C, et al. Usefulness of a chimeric anti-GD2 (ch14.18) and GM-CSF for refractory neuroblastoma: a POG phase II study. PROC ASCO. 1997;16:1846.

65. Ozkaynak MF, Sondel PM, Krailo MD, et al. Phase I study of chimeric human/murine anti-ganglioside G(D2) monoclonal antibody (ch14.18) with granulocyte-macrophage colony-stimulating factor in children with neuroblastoma immediately after hematopoietic stem-cell transplantation: a Children's Cancer Group Study. J Clin Oncol. 2000;18(24):4077-4085. doi:10.1200/ JCO.2000.18.24.4077

66. Simon T, Hero B, Faldum A, et al. Consolidation treatment with chimeric anti-GD2-antibody ch14.18 in children older than 1 year with metastatic neuroblastoma. $J$ Clin Oncol. 2004;22 (17):3549-3557. doi:10.1200/JCO.2004.08.143

67. Gilman AL, Ozkaynak MF, Matthay KK, et al. Phase I study of ch14.18 with granulocyte-macrophage colony-stimulating factor and interleukin-2 in children with neuroblastoma after autologous bone marrow transplantation or stem-cell rescue: a report from the Children's Oncology Group. J Clin Oncol. 2009;27(1):85-91. doi:10.1200/JCO.2006.10.3564
68. Mody R, Naranjo A, Van Ryn C, et al. Irinotecan-temozolomide with temsirolimus or dinutuximab in children with refractory or relapsed neuroblastoma (COG ANBL1221): an open-label, randomised, Phase 2 trial. Lancet Oncol. 2017;18(7):946-957. doi:10.1016/S1470-2045(17)30355-8

69. Mody R, Yu AL, Naranjo A, et al. Irinotecan, temozolomide, and dinutuximab with GM-CSF in children with refractory or relapsed neuroblastoma: a report from the Children's Oncology Group. J Clin Oncol. 2020;38(19):2160-2169. doi:10.1200/JCO.20.00203

70. EMA approval of dinutuximab beta; 2020. Available from: https://www.ema.europa.eu/en/medicines/human/EPAR/qarziba. Accessed September 10, 2020.

71. Ladenstein R, Weixler S, Baykan B, et al. Ch14.18 antibody produced in CHO cells in relapsed or refractory Stage 4 neuroblastoma patients: a SIOPEN Phase 1 study. mAbs. 2013;5 (5):801-809. doi:10.4161/mabs.25215

72. Ladenstein R, Potschger $U$, Valteau-Couanet $D$, et al. Investigation of the role of dinutuximab beta-based immunotherapy in the SIOPEN high-risk neuroblastoma 1 trial (HR-NBL1). Cancers. 2020;12(2):309. doi:10.3390/cancers12020309

73. Ladenstein R, Potschger U, Valteau-Couanet D, et al. Interleukin 2 with anti-GD2 antibody ch14.18/CHO (dinutuximab beta) in patients with high-risk neuroblastoma (HR-NBL1/SIOPEN): a multicentre, randomised, phase 3 trial. Lancet Oncol. 2018;19 (12):1617-1629. doi:10.1016/S1470-2045(18)30578-3

74. Mueller I, Ehlert K, Endres S, et al. Tolerability, response and outcome of high-risk neuroblastoma patients treated with long-term infusion of anti-GD2 antibody ch14.18/CHO. mAbs. 2018;10(1):55-61. doi:10.1080/19420862.2017.1402997

75. Harding FA, Stickler MM, Razo J, DuBridge RB. The immunogenicity of humanized and fully human antibodies: residual immunogenicity resides in the CDR regions. mAbs. 2010;2 (3):256-265. doi:10.4161/mabs.2.3.11641

76. Thommesen JE, Michaelsen TE, Loset GA, Sandlie I, Brekke $\mathrm{OH}$. Lysine 322 in the human $\operatorname{IgG} 3 \mathrm{C}(\mathrm{H}) 2$ domain is crucial for antibody dependent complement activation. MolImmunol. 2000;37(16):995-1004.

77. Navid F, Sondel PM, Barfield R, et al. Phase I trial of a novel anti-GD2 monoclonal antibody, Hu14.18K322A, designed to decrease toxicity in children with refractory or recurrent neuroblastoma. J Clin Oncol. 2014;32(14):1445-1452. doi:10. 1200/JCO.2013.50.4423

78. Anghelescu DL, Goldberg JL, Faughnan LG, et al. Comparison of pain outcomes between two anti-GD2 antibodies in patients with neuroblastoma. Pediatr Blood Cancer. 2015;62(2):224-228. doi: $10.1002 / \mathrm{pbc} .25280$

79. Furman WL, Federico SM, McCarville MB, et al. A phase II Trial of Hu14.18K322A in combination with induction chemotherapy in children with newly diagnosed high-risk neuroblastoma. Clin Cancer Res. 2019;25(21):6320-6328. doi:10.1158/1078-0432. CCR-19-1452

80. Ady N, Zucker JM, Asselain B, et al. A new 123I-MIBG whole body scan scoring method-application to the prediction of the response of metastases to induction chemotherapy in stage IV neuroblastoma. Eur J Cancer. 1995;31(2):256-261. doi:10.1016/ 0959-8049(94)00509-4

81. Cheung NK, Guo H, Hu J, Tassev DV, Cheung IY. Humanizing murine IgG3 anti-GD2 antibody m3F8 substantially improves antibody-dependent cell-mediated cytotoxicity while retaining targeting in vivo. Oncoimmunology. 2012;1(4):477-486. doi:10.4161/onci.19864

82. Kushner BH, Cheung IY, Modak S, Basu EM, Roberts SS, Cheung NK. Humanized 3F8 Anti-G D2 monoclonal antibody dosing with granulocyte-macrophage colony-stimulating factor in patients with resistant neuroblastoma. JAMA Oncol. 2018;4:1729. doi:10.1001/jamaoncol.2018.4005 
83. Wang W, Wang EQ, Balthasar JP. Monoclonal antibody pharmacokinetics and pharmacodynamics. Clin Pharmacol Ther. 2008;84(5):548-558. doi:10.1038/clpt.2008.170

84. Ryman JT, Meibohm B. Pharmacokinetics of monoclonal antibodies. CPT Pharmacometr Syst Pharmacol. 2017;6 (9):576-588. doi:10.1002/psp4.12224

85. Dostalek M, Gardner I, Gurbaxani BM, Rose RH, Chetty M. Pharmacokinetics, pharmacodynamics and physiologically-based pharmacokinetic modelling of monoclonal antibodies. Clin Pharmacokinet. 2013;52(2):83-124.

86. Deng R, Jin F, Prabhu S, Iyer S. Monoclonal antibodies: what are the pharmacokinetic and pharmacodynamic considerations for drug development? Expert Opin Drug Metab Toxicol. 2012;8(2):141-160. doi:10.1517/17425255.2012.643868

87. Lobo ED, Hansen RJ, Balthasar JP. Antibody pharmacokinetics and pharmacodynamics. J Pharm Sci. 2004;93(11):2645-2668. doi:10.1002/jps.20178

88. Siebert N, Eger C, Seidel D, et al. Pharmacokinetics and pharmacodynamics of ch14.18/CHO in relapsed/refractory high-risk neuroblastoma patients treated by long-term infusion in combination with IL-2. mAbs. 2016.

89. Ladenstein RL, Poetschger U, Valteau-Couanet D, et al. Randomization of dose-reduced subcutaneous interleukin-2 (scIL2) in maintenance immunotherapy (IT) with anti-GD2 antibody dinutuximab beta (DB) long-term infusion (LTI) in front line high-risk neuroblastoma patients: early results from the HR-NBL1/SIOPEN trial. J Clin Oncol. 2019;37(15).

90. Desai AV, Fox E, Smith LM, Lim AP, Maris JM, Balis FM. Pharmacokinetics of the chimeric anti-GD2 antibody, ch14.18, in children with high-risk neuroblastoma. Cancer Chemother Pharmacol. 2014;74(5):1047-1055. doi:10.1007/s00280-0142575-9

91. Yeh SD, Larson SM, Burch L, et al. Radioimmunodetection of neuroblastoma with iodine-131-3F8: correlation with biopsy, iodine-131-metaiodobenzylguanidine and standard diagnostic modalities. J Nucl Med. 1991;32(5):769-776.

92. Reuland P, Geiger L, Thelen MH, et al. Follow-up in neuroblastoma: comparison of metaiodobenzylguanidine and a chimeric anti-GD2 antibody for detection of tumor relapse and therapy response. J Pediatr Hematol Oncol. 2001;23(7):437-442. doi:10.1097/00043426-200110000-00009

93. Vavere AL, Butch ER, Dearling JL, et al. 64Cu-p-NH2-Bn-DOTA -hu14.18K322A, a PET radiotracer targeting neuroblastoma and melanoma. J Nucl Med. 2012;53(11):1772-1778. doi:10.2967/ jnumed.112.104208

94. Modak S, Cheung NK. Antibody-based targeted radiation to pediatric tumors. $J$ Nucl Med. 2005;46(Suppl 1):157 S-163S.

95. Cheung NK, Kushner BH, LaQuaglia M, et al. N7: a novel multi-modality therapy of high risk neuroblastoma (NB) in children diagnosed over 1 year of age. Med Pediatr Oncol. 2001;36 (1):227-230. doi:10.1002/1096-911X(20010101)36:1<227::AIDMPO1055>3.0.CO;2-U

96. Sondel PM, Hank JA. Combination therapy with interleukin-2 and antitumor monoclonal antibodies. Cancer J Sci Am. 1997;3 (Suppl 1):S121-127.

97. Nguyen R, Houston J, Chan WK, Finkelstein D, Dyer MA. The role of interleukin-2, all-trans retinoic acid, and natural killer cells: surveillance mechanisms in anti-GD2 antibody therapy in neuroblastoma. Cancer Immunol Immunother. 2018;67 (4):615-626. doi:10.1007/s00262-017-2108-6

98. Ribeiro RC, Rill D, Roberson PK, et al. Continuous infusion of interleukin-2 in children with refractory malignancies. Cancer. 1993;72(2):623-628. doi:10.1002/1097-0142(19930715) $72: 2<623::$ AID-CNCR2820720248>3.0.CO;2-S
99. Yang RK, Kalogriopoulos NA, Rakhmilevich AL, et al. Intratumoral hu14.18-IL-2 (IC) induces local and systemic antitumor effects that involve both activated T and NK cells as well as enhanced IC retention. J Immunol. 2012;189(5):2656-2664. doi:10.4049/jimmunol.1200934

100. Yamane BH, Hank JA, Albertini MR, Sondel PM. The development of antibody-IL-2 based immunotherapy with hu14.18-IL2 (EMD-273063) in melanoma and neuroblastoma. Expert Opin Investig Drugs. 2009;18(7):991-1000. doi:10.1517/13543780 903048911

101. Osenga KL, Hank JA, Albertini MR, et al. A phase I clinical trial of the hu14.18-IL2 (EMD 273063) as a treatment for children with refractory or recurrent neuroblastoma and melanoma: a study of the Children's Oncology Group. Clin Cancer Res. 2006;12 (6):1750-1759. doi:10.1158/1078-0432.CCR-05-2000

102. Shusterman S, London WB, Gillies SD, et al. Antitumor activity of hu14.18-IL2 in patients with relapsed/refractory neuroblastoma: a Children's Oncology Group (COG) phase II study. J Clin Oncol. 2010;28(33):4969-4975. doi:10.1200/JCO.2009. 27.8861

103. Alvarez-Rueda N, Desselle A, Cochonneau D, et al. A monoclonal antibody to O-acetyl-GD2 ganglioside and not to GD2 shows potent anti-tumor activity without peripheral nervous system cross-reactivity. PLoS One. 2011;6(9):e25220. doi:10. 1371/journal.pone.0025220

104. Terme M, Dorvillius M, Cochonneau D, et al. Chimeric antibody c.8B6 to O-acetyl-GD2 mediates the same efficient anti-neuroblastoma effects as therapeutic ch14.18 antibody to GD2 without antibody induced allodynia. PLoS One. 2014;9(2): e87210. doi:10.1371/journal.pone.0087210

105. Fleurence J, Fougeray S, Bahri M, et al. Targeting O-Acetyl-GD2 ganglioside for cancer immunotherapy. $J$ Immunol Res. 2017;2017:5604891. doi:10.1155/2017/5604891

106. Castriconi R, Dondero A, Augugliaro R, et al. Identification of 4Ig-B7-H3 as a neuroblastoma-associated molecule that exerts a protective role from an NK cell-mediated lysis. Proc Natl Acad Sci U S A. 2004;101(34):12640-12645. doi:10.1073/ pnas.0405025101

107. Gregorio A, Corrias MV, Castriconi R, et al. Small round blue cell tumours: diagnostic and prognostic usefulness of the expression of B7-H3 surface molecule. Histopathology. 2008;53 (1):73-80. doi:10.1111/j.1365-2559.2008.03070.x

108. Picarda E, Ohaegbulam KC, Zang X. Molecular pathways: targeting B7-H3 (CD276) for human cancer immunotherapy. Clin Cancer Res. 2016;22(14):3425-3431. doi:10.1158/1078-0432. CCR-15-2428

109. Du H, Hirabayashi K, Ahn S, et al. Antitumor responses in the absence of toxicity in solid tumors by targeting B7-H3 via chimeric antigen receptor T cells. Cancer Cell. 2019;35(2):221-237 e228. doi:10.1016/j.ccell.2019.01.002

110. Modak S, Kramer K, Gultekin SH, Guo HF, Cheung NK. Monoclonal antibody $8 \mathrm{H} 9$ targets a novel cell surface antigen expressed by a wide spectrum of human solid tumors. Cancer Res. 2001;61(10):4048-4054.

111. Ahmed M, Cheng M, Zhao Q, et al. Humanized affinity-matured monoclonal antibody $8 \mathrm{H} 9$ has potent antitumor activity and binds to FG loop of tumor antigen B7-H3. J Biol Chem. 2015;290 (50):30018-30029. doi:10.1074/jbc.M115.679852

112. Kramer K, Kushner B, Modak S, et al. A curative approach to central nervous system metastases of neuroblastoma. Pediatr Blood Cancer. 2019;66:S56-S56.

113. Kramer K, Kushner BH, Modak S, et al. A curative approach to central nervous system metastases of neuroblastoma. J Clin Oncol. 2017;35:10545. doi:10.1200/JCO.2017.35.15_ suppl.10545 
114. Desantes K, Maris JM, McDowell K, et al. A phase 1, open-label, dose escalation study of enoblituzumab (MGA271) in pediatric patients with B7-H3-expressing relapsed or refractory solid tumors. J Clin Oncol. 2017;35:TPS2596-TPS2596. doi:10.1200/ JCO.2017.35.15_suppl.TPS2596

115. Bresler SC, Weiser DA, Huwe PJ, et al. ALK mutations confer differential oncogenic activation and sensitivity to ALK inhibition therapy in neuroblastoma. Cancer Cell. 2014;26(5):682-694. doi:10.1016/j.ccell.2014.09.019

116. Carpenter EL, Haglund EA, Mace EM, et al. Antibody targeting of anaplastic lymphoma kinase induces cytotoxicity of human neuroblastoma. Oncogene. 2012;31(46):4859-4867. doi:10.1038/ onc. 2011.647

117. Dondero A, Pastorino F, Della Chiesa M, et al. PD-L1 expression in metastatic neuroblastoma as an additional mechanism for limiting immune surveillance. Oncoimmunology. 2016;5(1):e1064578. doi:10.1080/2162402X.2015.1064578

118. Siebert N, Zumpe M, Juttner M, Troschke-Meurer S, Lode HN. PD-1 blockade augments anti-neuroblastoma immune response induced by anti-GD2 antibody ch14.18/CHO. Oncoimmunology. 2017;6(10):e1343775. doi:10.1080/2162402X.2017.1343775

119. Ehlert K, Hansjuergens I, Zinke A, et al. Nivolumab and dinutuximab beta in two patients with refractory neuroblastoma. $J$ Immunother Cancer. 2020;8(1):e000540. doi:10.1136/jitc-2020-000540

120. Li N, Gao W, Zhang YF, Ho M. Glypicans as cancer therapeutic targets. Trends Cancer. 2018;4(11):741-754. doi:10.1016/j. trecan.2018.09.004

121. Bosse KR, Raman P, Zhu Z, et al. Identification of GPC2 as an oncoprotein and candidate immunotherapeutic target in high-risk neuroblastoma. Cancer Cell. 2017;32(3):295-309 e212. doi:10.1016/j.ccell.2017.08.003

122. Theocharopoulos C, Lialios PP, Gogas H, Ziogas DC. An overview of antibody-drug conjugates in oncological practice. Ther Adv Med Oncol. 2020;12:1758835920962997. doi:10.1177/ 1758835920962997

123. Zhang W, Huang Q, Xiao W, et al. Advances in anti-tumor treatments targeting the CD47/SIRPalpha axis. Front Immunol. 2020;11:18. doi:10.3389/fimmu.2020.00018

124. Aktas S, Ozdemir A, Serinan E, Altun Z, Olgun N. "Don't Eat Me" signals of neuroblastoma by CD47 for immune escape: a novel prognostic biomarker. Proceedings. 2018;2(25):1538. doi:10.3390/proceedings2251538

125. Oronsky B, Carter C, Reid T, Brinkhaus F, Knox SJ. Just eat it: a review of CD47 and SIRP-alpha antagonism. Semin Oncol. 2020;47(2-3):117-124. doi:10.1053/j.seminoncol.2020.05.009

126. Jaiswal S, Jamieson CH, Pang WW, et al. CD47 is upregulated on circulating hematopoietic stem cells and leukemia cells to avoid phagocytosis. Cell. 2009;138(2):271-285. doi:10.1016/j.cell.20 09.05 .046

127. Asgharzadeh S, Salo JA, Ji L, et al. Clinical significance of tumor-associated inflammatory cells in metastatic neuroblastoma. J Clin Oncol. 2012;30(28):3525-3532. doi:10. 1200/JCO.2011.40.9169

128. Theruvath J, Smith B, Linde MH, et al. Abstract PR07: GD2 is a macrophage checkpoint molecule and combined GD2/CD47 blockade results in synergistic effects and tumor clearance in xenograft models of neuroblastoma and osteosarcoma. Cancer Res. 2020;80(14Supplement):PR07.

129. Labrijn AF, Janmaat ML, Reichert JM, Parren P. Bispecific antibodies: a mechanistic review of the pipeline. Nat Rev Drug Discov. 2019;18(8):585-608. doi:10.1038/s41573-019-0028-1

130. Yankelevich M, Kondadasula SV, Thakur A, Buck S, Cheung NK, Lum LG. Anti-CD3 x anti-GD2 bispecific antibody redirects T-cell cytolytic activity to neuroblastoma targets. Pediatr Blood Cancer. 2012;59(7):1198-1205. doi:10.1002/ pbc. 24237
131. Hernandez R, Erbe A, Gerhardt D, et al. GD2/B7-H3 bispecific antibodies for next-generation neuroblastoma treatment $</$ strong $>$. J Nucl Med. 2020;61(supplement1):376.

132. Erbe A, Gerhardt D, Hernandez R, et al. Improving specific targeting of tumors through bispecific sniper antibodies. $J$ Immunother Cancer. 2020;8:A280-A280. doi:10.1136/jitc2020-SITC2020.0461

133. Mori K, Iida S, Yamane-Ohnuki N, et al. Non-fucosylated therapeutic antibodies: the next generation of therapeutic antibodies. Cytotechnology. 2007;55(2-3):109-114. doi:10.1007/s10616007-9103-2

134. Shields RL, Lai J, Keck R, et al. Lack of fucose on human IgG1 $\mathrm{N}$-linked oligosaccharide improves binding to human Fcgamma RIII and antibody-dependent cellular toxicity. J Biol Chem. 2002;277(30):26733-26740. doi:10.1074/jbc.M202069200

135. Hank JA, Robinson RR, Surfus J, et al. Augmentation of antibody dependent cell mediated cytotoxicity following in vivo therapy with recombinant interleukin 2. Cancer Res. 1990;50(17):5234-5239.

136. Tanaka A, Sakaguchi S. Regulatory T cells in cancer immunotherapy. Cell Res. 2017;27(1):109-118. doi:10.1038/cr.2016.151

137. Lode H, Siebert N, Troschke-Meurer S, et al. Administration of subcutaneous IL-2 is associated with strong induction of regulatory $\mathrm{T}$ cells in high-risk neuroblastoma patients treated with dinutuximab beta, a SIOPEN study. Pediatr Blood Cancer. 2019;66:S55-S56.

138. Nguyen R, Moustaki A, Norrie JL, et al. Interleukin-15 enhances anti-GD2 antibody-mediated cytotoxicity in an orthotopic PDX model of neuroblastoma. Clin Cancer Res. 2019;25 (24):7554-7564. doi:10.1158/1078-0432.CCR-19-1045

139. Heinze A, Grebe B, Bremm M, et al. The synergistic use of IL-15 and IL-21 for the generation of NK cells from CD3/ CD19-depleted grafts improves their ex vivo expansion and cytotoxic potential against neuroblastoma: perspective for optimized immunotherapy post haploidentical stem cell transplantation. Front Immunol. 2019;10. doi:10.3389/fimmu.2019.02816

140. Nowak AK, Robinson BW, Lake RA. Synergy between chemotherapy and immunotherapy in the treatment of established murine solid tumors. Cancer Res. 2003;63(15):4490-4496.

141. Lake RA, Robinson BW. Immunotherapy and chemotherapy-a practical partnership. Nat Rev Cancer. 2005;5(5):397-405. doi:10.1038/nrc1613

142. Buhtoiarov IN, Sondel PM, Wigginton JM, et al. Anti-tumour synergy of cytotoxic chemotherapy and anti-CD40 plus CpG-ODN immunotherapy through repolarization of tumour-associated macrophages. Immunology. 2011;132 (2):226-239. doi:10.1111/j.1365-2567.2010.03357.x

143. Holden SA, Lan Y, Pardo AM, Wesolowski JS, Gillies SD. Augmentation of antitumor activity of an antibody-interleukin 2 immunocytokine with chemotherapeutic agents. Clin Cancer Res. 2001;7(9):2862-2869.

144. Ghiringhelli F, Larmonier N, Schmitt E, et al. CD4+CD25+ regulatory $\mathrm{T}$ cells suppress tumor immunity but are sensitive to cyclophosphamide which allows immunotherapy of established tumors to be curative. Eur J Immunol. 2004;34(2):336-344. doi:10.1002/eji.200324181

145. Menard C, Martin F, Apetoh L, Bouyer F, Ghiringhelli F. Cancer chemotherapy: not only a direct cytotoxic effect, but also an adjuvant for antitumor immunity. Cancer Immunol Immunother. 2008;57(11):1579-1587. doi:10.1007/s00262-008-0505-6

146. Zitvogel L, Apetoh L, Ghiringhelli F, Kroemer G. Immunological aspects of cancer chemotherapy. Nat Rev Immunol. 2008;8 (1):59-73. doi:10.1038/nri2216

147. Raffaghello L, Marimpietri D, Pagnan G, et al. Anti-GD2 monoclonal antibody immunotherapy: a promising strategy in the prevention of neuroblastoma relapse. Cancer Lett. 2003;197 (1-2):205-209. doi:10.1016/S0304-3835(03)00100-9 
148. Nowak AK, Lake RA, Marzo AL, et al. Induction of tumor cell apoptosis in vivo increases tumor antigen cross-presentation, cross-priming rather than cross-tolerizing host tumor-specific CD8 T cells. J Immunol. 2003;170(10):4905-4913. doi:10.4049/ jimmunol.170.10.4905

149. Park JA, Cheung NV. Targets and antibody formats for immunotherapy of neuroblastoma. $J$ Clin Oncol. 2020;38 (16):1836-1848. doi:10.1200/JCO.19.01410

150. Richards RM, Sotillo E, Majzner RG. CAR T cell therapy for neuroblastoma. Front Immunol. 2018;9:2380. doi:10.3389/ fimmu.2018.02380

151. Heczey A, Louis CU. Advances in chimeric antigen receptor immunotherapy for neuroblastoma. Discov Med. 2013;16 (90):287-294.

152. Louis CU, Savoldo B, Dotti G, et al. Antitumor activity and long-term fate of chimeric antigen receptor-positive $\mathrm{T}$ cells in patients with neuroblastoma. Blood. 2011;118(23):6050-6056. doi:10.1182/blood-2011-05-354449

153. Oh S, Lee JH, Kwack K, Choi SW. Natural killer cell therapy: a new treatment paradigm for solid tumors. Cancers. 2019;11 (10):1534. doi: $10.3390 /$ cancers 11101534
154. Mehta RS, Rezvani K. Chimeric antigen receptor expressing natural killer cells for the immunotherapy of cancer. Front Immunol. 2018;9:283. doi:10.3389/fimmu.2018.00283

155. Modak S, Le Luduec JB, Cheung IY, et al. Adoptive immunotherapy with haploidentical natural killer cells and Anti-GD2 monoclonal antibody $\mathrm{m} 3 \mathrm{~F} 8$ for resistant neuroblastoma: results of a phase I study. Oncoimmunology. 2018;7(8):e1461305. doi:10.1080/2162402X.2018.1461305

156. Barry WE, Jackson JR, Asuelime GE, et al. Activated natural killer cells in combination with anti-GD2 antibody dinutuximab improve survival of mice after surgical resection of primary neuroblastoma. Clin Cancer Res. 2018;25:325-333. doi:10.1158/ 1078-0432.CCR-18-1317

157. Uttenreuther-Fischer MM, Huang CS, Reisfeld RA, Yu AL. Pharmacokinetics of anti-ganglioside GD2 mAb 14G2a in a phase 1 trial in pediatric cancer patients. Cancer Immunol Immunother. 1995;41:29-36.

158. Kramer K, Cheung NK, Humm JL, et al. Targeted radioimmunotherapy for leptomeningeal cancer using (131)I-3F8. Med Pediatr Oncol. 2000;35:716-8.

\section{Publish your work in this journal}

Biologics: Targets and Therapy is an international, peer-reviewed journal focusing on the patho-physiological rationale for and clinical application of Biologic agents in the management of autoimmune diseases, cancers or other pathologies where a molecular target can be identified. This journal is indexed on PubMed Central, CAS, EMBase,
Scopus and the Elsevier Bibliographic databases. The manuscript management system is completely online and includes a very quick and fair peer-review system, which is all easy to use. Visit $\mathrm{http}: / / \mathrm{www}$.dovepress.com/testimonials.php to read real quotes from published authors. 